\title{
Exocrine Pancreatic Insufficiency in Type 1 and Type 2 Diabetes
}

\author{
Bernhard Radlinger ${ }^{1} \cdot$ Gabriele Ramoser $^{2} \cdot$ Susanne Kaser ${ }^{1}$
}

Published online: 1 April 2020

(C) The Author(s) 2020

\begin{abstract}
Purpose of Review Type 1 and type 2 diabetes are often accompanied by mostly mild forms of exocrine pancreatic insufficiency. Despite high prevalence, little is known about the clinical consequences of exocrine pancreatic insufficiency and its optimal (nutritional) treatment. Even less is known if and to what extent exocrine pancreas insufficiency also affects glycemic control in diabetes. This article aims for summarizing current clinical knowledge on screening, diagnosis, and treatment and gives an overview on the pathophysiology of exocrine pancreatic insufficiency in diabetes.

Recent Findings Recent studies reveal novel insights into the close interaction of acinar, ductal, and endocrine cells and the gutpancreas axis.

Summary Exocrine pancreatic insufficiency is a clinically relevant, frequent but poorly understood disorder in both type 1 and type 2 diabetes.
\end{abstract}

Keywords Diabetes mellitus $\cdot$ Exocrine pancreatic insufficiency $\cdot$ Fecal elastase $\cdot$ Islet-acinar axis

\section{Introduction}

Exocrine pancreatic insufficiency (EPI or pancreatic exocrine insufficiency (PEI)) also named exocrine pancreatic dysfunction (EPD) or pancreatic maldigestion is defined as malabsorption resulting from insufficient digestion of nutrients, especially fats $[1,2]$. EPI is caused by insufficient secretion of pancreatic enzymes such as amylase, lipase, and protease and/ or sodium bicarbonate. Clinical symptoms including steatorrhea, weight loss, excess flatulence, abdominal discomfort and clinical signs of vitamin (A, D, E, K), and albumin deficiency usually occur when pancreatic enzyme activity is lower than $10 \%[2-4]$.

This article is part of the Topical Collection on Other Forms of Diabetes and Its Complications

Susanne Kaser

susanne.kaser@i-med.ac.at

1 Department of Internal Medicine 1, Medical University Innsbruck, Anichstrasse 35, 6020 Innsbruck, Austria

2 Department of Pediatrics II, Medical University Innsbruck, Innsbruck, Austria

\section{Prevalence}

While the frequency of EPI in otherwise healthy persons is unclear [3], several disorders including different types of diabetes are associated with significantly increased risk for EPI. By definition, EPI is found in nearly all patients with pancreatogenic diabetes [5], therefore studies on the prevalence of EPI in patients with diabetes are typically focused on type 1 and type 2 diabetes. In the past, EPI diagnosed via direct pancreatic function tests was thought to be present in about $50 \%$ of patients with diabetes [6]. However, direct pancreatic function tests were replaced by non-invasive, cheaper tests showing partly different EPI frequency rates [6]. Nowadays, determination of fecal elastase-1 (FE-1) concentration is most frequently used for diagnosing EPI in clinical and epidemiological studies. FE-1 is regarded as a suitable indicator of pancreatic enzyme secretion as it passes the intestinal tract in an unmodified way and does not get secreted/ ingested past the pancreas [7].

In a recent study, $12.7 \%$ of patients with diabetes were diagnosed with EPI as defined by FE-1 levels $<200 \mu \mathrm{g} / \mathrm{g}$ stool. Prevalence of EPI was higher in type 1 diabetes than in type 2 diabetes [8]. In this study, diabetes duration turned out to be a risk factor of EPI, while in others, no association between diabetes duration and EPI was found [9-11]. In 
contrast to this small sample size study, Hardt and colleagues [12] reported reduced FE-1 concentrations in $40.7 \%$ of patients with long-standing diabetes. Frequency rates were comparable between patients with either type 1 or type 2 diabetes, and type of treatment had no effect on EPI risk in patients with type 2 diabetes [12]. Lower EPI rates were reported by Larger and colleagues [13] who found that in total $20.3 \%$ of patients suffering from either type 1 or type 2 diabetes had significantly reduced FE-1 levels. No information on severity of symptoms in affected patients was available from these studies.

In a meta-analysis of 17 studies including 3662 subjects with diabetes, EPI - defined by decreased FE-1 concentrations $\leq 200 \mu \mathrm{g} / \mathrm{g}$ stool - was reported in $38.62 \%$ of patients with type 1 diabetes and $28.12 \%$ of patients with type 2 diabetes [14]. Remarkably, in a previous study of patients with type 1 diabetes, $40 \%$ had a normal fat excretion $(<7 \mathrm{~g} /$ day on a $100 \mathrm{~g}$ fat/day diet) despite markedly decreased FE-1 levels ( $\leq 100 \mu \mathrm{g} / \mathrm{g}$ stool). On the other hand, only $12 \%$ of patients with significantly reduced FE-1 levels had strongly increased fecal fat excretion of more than $15 \mathrm{~g} /$ day [15]. Similarly, in another study, only 8 from 19 patients with type 1 diabetes with fecal fat excretions $>7 \mathrm{~g} /$ day had FE-1 levels $\leq 200 \mu \mathrm{g} / \mathrm{g}$ stool, while fecal fat excretions $>7 \mathrm{~g} /$ day were found in only 5 of 7 patients with FE- 1 concentrations $\leq 100 \mu \mathrm{g} / \mathrm{g}$ stool [9]. In accordance with these findings, Hahn and colleagues suggested that neither FE-1 concentrations nor increased fecal fat levels were reliable predictors of EPI as diagnosed by the gold standard secretin-cerulein test in patients with type 1 diabetes [16].

In type 2 diabetes, neither indigestion nor diarrhea is more frequent in patients with low FE-1 concentrations when compared with those with intermediate or normal FE-1 levels. However, 25-OH-vitamin D and lipase concentrations were significantly decreased in patients with low FE-1 concentrations [17].

Bariatric surgery is considered as additional and optional treatment in obese patients with type 2 diabetes. Notably, in a cohort of mainly non-diabetic obese subjects, $31 \%$ of patients developed EPI after Roux-en-Y gastric bypass surgery [18].

\section{Clinical Consequences of EPI}

Symptoms of EPI are usually mild to moderate in affected patients with diabetes. In severe disease, these include steatorrhea and weight loss, while in mild and moderate disease, typically abdominal discomfort or pain, diarrhea, and flatulence might be misdiagnosed as drug-induced (metformin, glucagon-like peptide 1 (GLP-1) agonists) (Fig. 1) [6]. Studies showing only weak correlations between fecal fat excretion, functional pancreas tests and FE-1 levels in patients with diabetes further underline the necessity of considering other differential diagnosis of steatorrhea such as celiac disease, bacterial overgrowth in the proximal small bowel, or poor glycemic control in patients with diabetes $[9,16]$. In a very recent population-based study, a close association between pancreatic elastase and microbial diversity was shown underlining the complex interaction between gut and exocrine pancreas. In this study patients with EPI defined as FE- $1<$ $200 \mu \mathrm{g} / \mathrm{g}$ stool showed an overall less diverse microbial composition and an increase in species associated with chronic inflammation. Results were also correlated with factors like age, sex, smoking, BMI, and dietary habits, however, none of these factors explained more changes in the bacterial composition than did fecal elastase levels [19••].

In patients with EPI due to chronic pancreatitis, increased rates of deficiencies of vitamins $\mathrm{E}, \mathrm{D}$, and $\mathrm{K}$ as well as osteopenia and osteoporosis were reported [20]. In another study, presence of EPI was associated with sarcopenia [21]. However, from the literature, it is not clear whether these data are applicable to diabetic patients with EPI also.

\section{Pathophysiological Aspects of EPI in Diabetes}

The etiology of EPI in diabetes is not fully clear yet. In the literature, pathophysiological aspects were more often investigated in settings of (autoimmune) insulin deprivation than in states of insulin resistance and hyperinsulinemia. Proposed factors include diminished trophic effects of insulin, inflammation, fibrosis, and steatosis which are summarized in detail here. Additionally, diabetic microangiopathy leading to ischemia in the exocrine pancreas and impaired enteropancreatic reflexes due to autonomic neuropathy have been discussed controversially to contribute to the development of EPI [6, 22-24].

\section{Islet-Acinar Axis}

Already in 1962, Hellman and colleagues reported a halo effect in detail around pancreatic islets [25] which results from islet surrounding acinar cells being the first cells to get in contact with the islet's secretome via a capillary network. The intricate vascular anatomy of the pancreas comprises of islets receiving an over proportional amount of arterial blood compared with the exocrine compartment and the exocrine pancreas receiving a fair share of this blood directly via special islet-acinar portal vessels [26-29] (Fig. 2). Due to the nature of the vascular system in the pancreas, local peri-islet insulin levels are likely to be very high compared with systemic levels, considering that even after dilution into the portal vein, insulin levels are roughly twice as high as compared with systemic circulation [30]. The trophic effect of insulin on acinar cells is well established: insulin downregulates its specific receptor in acinar cells and upregulates the synthesis of digestive enzymes [31-33]. Additionally, glucose uptake is 
Fig. 1 Proposed diagnostic approach in symptomatic patients with diabetes. Adapted from Kaser S et al. [75]

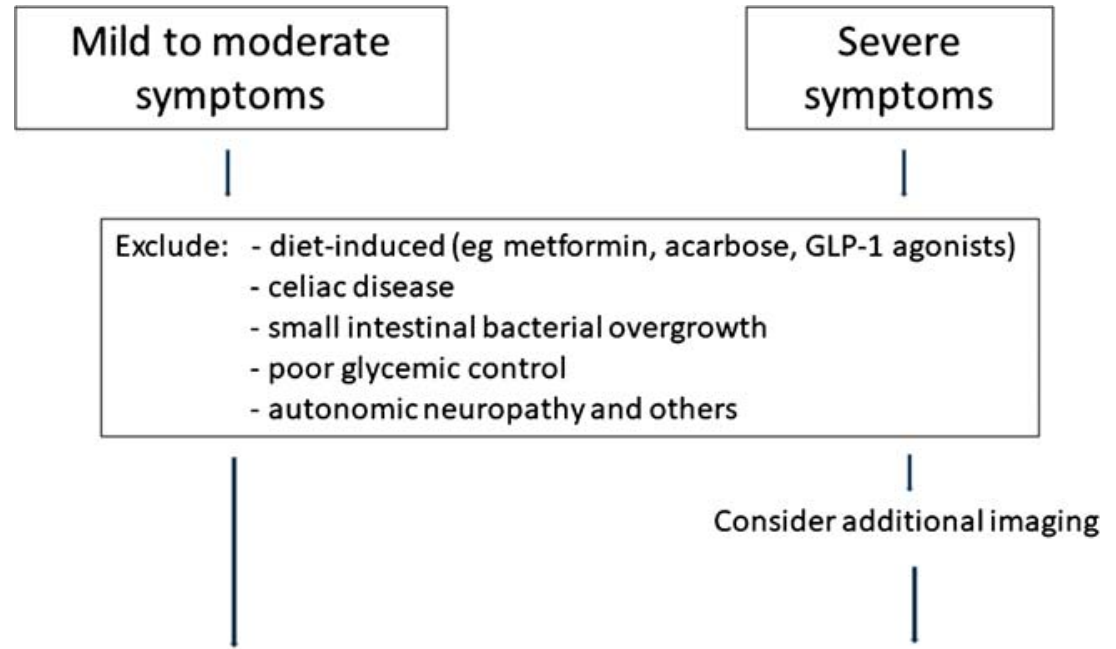

FE-1 testing ( $<200 \mu \mathrm{g} / \mathrm{g}$ stool)

Dietary counselling, pancreatic enzyme replacement therapy

increased upon insulin exposure to acinar cells [34]. Underlining the trophic effects of insulin on acinar cells, acinar atrophy was most pronounced around insulin-deficient islets compared with insulin expressing islets in autopsies of patients with type 1 diabetes [35].

Interestingly, type 2 diabetes and obesity are associated with increased pancreatic duct cell replication [36] and not until recently it has been shown that in states of increased insulin demand, ductal cells contribute to the compensatory $\beta$ cell pool by differentiation and/or neogenesis [37••].

Besides insulin, endocrine pancreatic islets also produce glucagon, somatostatin, ghrelin, pancreatic polypeptide, and other peptide hormones, which are involved in the regulation of the islet-acinar axis. Dysregulation or deficiency of these hormones in diabetes is thought to also contribute to EPI. Detailed biological effects of these substances on nearby acinar cells have been reviewed in detail recently [38].

Despite the delicate intra-organ crosstalk between islets and exocrine acini, there is a considerable size difference between these two compartments with islets only making 1-2\% of total pancreas mass [39]. Therefore, size estimates of total pancreas mass, either with direct measurement from autopsies, ultrasound scans, or with CT/MRI scans, mainly reflect the size of the exocrine pancreas. Remarkably, total, parenchymal, and fat volume increases with obesity, while no enlargement of fat volume were reported in patients with type 2 diabetes [40].

In general, the mean pancreas size of patients with type 1 diabetes is significantly decreased [41], probably resulting from lacking trophic effects of insulin. However, also the pancreata of patients with type 2 diabetes are smaller when compared with healthy controls [42]. Interestingly, Philippe et al. reported that reduced pancreas size in patients with either type 1 or type 2 diabetes is also associated with presence of exocrine pancreatic insufficiency [43].

\section{Fibrosis and Steatosis}

Besides a mere change in size, studies in different diabetes animal models suggest a loss of extracellular matrix remodeling with a focus in collagen deposition, especially at the isletacinar interface, together with increased angiogenesis $[26,44$, 45]. Accordingly, a recent meta-analysis reported that $59.4 \%$ of patients with either type 1 or type 2 diabetes show histopathological signs of fibrosis in the exocrine part of the pancreas [14]. Mechanistically, pancreatic stellate cells (PSC) seem to be crucial drivers of pancreatic fibrosis. Cytokines such as platelet-derived growth factor (PDGF) and transforming growth factor $\beta$ (TGF- $\beta$ ) and hyperglycemia lead to activation of PSC resulting in increased collagen production [46-48]. Besides fibrosis, diabetes is also associated with ectopic fat deposition in the pancreas. From the literature, it is unclear whether pancreatic steatosis is a cause or consequence of $\beta$ cell failure, hyperglycemia, and increased levels of fatty acids $[49,50]$. Its role in exocrine pancreatic insufficiency is even less clear: association studies between pancreatic fat content and FE-1 levels showed mixed results [51, 52].

\section{Inflammation}

While immune cell infiltration of islets in type 1 diabetes is well known, Rodriguez-Calvo et al. [53] found high CD8+ T cells infiltration in the exocrine pancreas of type 1 diabetic patients also. Remarkably, high immune cell infiltration of 


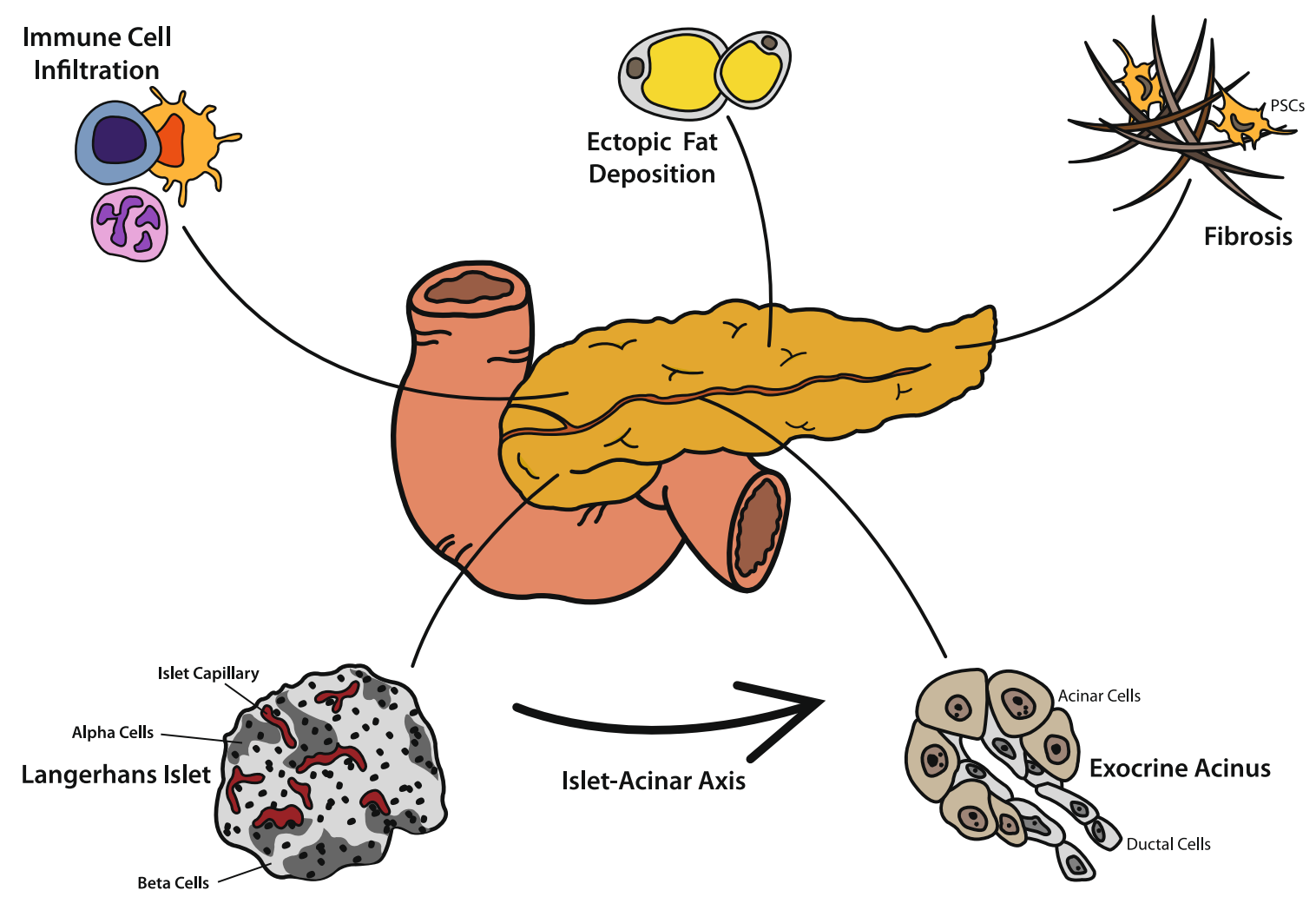

Fig. 2 Contributing factors to exocrine pancreatic insufficiency in patients with diabetes. Due to portal vessels supplying exocrine acini with the secretome of endocrine islets, acinar cells are under endocrine control, in the short-term for well-regulated upregulation of pancreatic enzyme secretion and in the long-term for trophic control of both acinar cells and ductal cells. Overall and with time, the pancreata in patients with type 1 or type 2 diabetes get atrophic and exocrine function declines. Islet microvasculature might be affected by diabetic microangiopathy, and diabetic neuropathy is also discussed to influence this islet-acinar axis

the exocrine compartment was reported even without apparent insulitis in patients with type 1 diabetes. In long-standing diabetes, not only CD8+ T cells but also CD4+ T cells and $\mathrm{CD} 11 \mathrm{c}+$ cells were found in the exocrine pancreas. The pathophysiological role of immune cells in acinar atrophy and fibrosis is not clear. Noteworthy, type 2 diabetes is also associated with increased immune cell infiltration of the exocrine pancreas [53, 54].

Additionally, autoantibodies raised against exocrine antigens have been observed in up to $39 \%$ of patients with type 1 diabetes and in $0.9 \%$ of patients with type 2 diabetes [54]. Autoantibodies targeting the pancreatic enzyme bile saltdependent lipase were found in $73.5 \%$ of patients with type 1 diabetes [55].

\section{Diagnostic Approach and Treatment}

Invasive, expensive and time-consuming functional pancreatic tests including the secretin-cholecystokinin (CCK) or secretin-cerulein stimulation tests were considered as gold

(not depicted specifically in this figure). Immune cell infiltration (mainly CD8+, CD4+, and CD11c+ cells) and autoantibodies targeting the exocrine compartment are frequently found in both type 1 and in type 2 diabetes. A rise in collagen deposition and loss of extracellular matrix remodeling facilitated by activated pancreatic stellate cells (PSCs) lead to an increased rate of pancreatic fibrosis in patients with diabetes. Additionally, ectopic fat accumulation has been discussed to contribute to development of EPI, however, data from the literature are controversial

standard for diagnosis of EPI in the past [56]. Nowadays, the 72-h fecal fat test serves as gold standard for the quantification of steatorrhea, however, it has significant limitations in detecting mild to moderate EPI [7]. ${ }^{13} \mathrm{C}$-breath tests including the ${ }^{13} \mathrm{C}$-mixed triglyceride breath test are also time-consuming and thus not frequently used in daily clinical routine [57-60].

In clinical practice, determination of FE-1 is commonly used as a marker of EPI. Elastase-1 is synthesized and secreted by pancreatic acinar cells and then passes the intestinal tract with minimal degradation after binding to bile salts [7]. Fecal levels of elastase-1 highly correlate with pancreatic elastase- 1 secretion but also with amylase, lipase, and trypsin [61, 62]. False positive results are common in patients with diarrhea and might be avoided by lyophilization of feces and adjustment to a standardized water content [63]. Sensitivity and specificity of the FE-1 test is highly dependent on the severity of symptoms. A FE- 1 cutoff $\leq 200 \mu \mathrm{g} / \mathrm{g}$ stool indicates EPI, while FE-1 concentrations of less than $\leq 100 \mu \mathrm{g} / \mathrm{g}$ stool are indicative of severe EPI [64]. In subjects with pancreatic disease, the mean sensitivity using a cutoff $\leq 200 \mu \mathrm{g} / \mathrm{g}$ stool was $63 \%$ in mild deficiency and $100 \%$ in moderate-to-severe EPI with a specificity of 
93\% when compared with the secretin-CCK or secretincerulein test [65]. In a meta-analysis of 8 studies, the sensitivity of the FE- 1 test was calculated as $54 \%$ for mild, $75 \%$ for moderate, and $95 \%$ for severe EPI, while overall specificity was $79 \%$ in this study [66]. Considering the high prevalence of EPI in patients with diabetes, screening of symptomatic patients, especially those with nutritional deficiencies using the FE-1 test might be useful [67].

Therapy of EPI is based on both dietary counseling and administration of exogenous pancreatic enzymes. Generally, fat restriction and very high-fiber diets are recommended to be avoided in symptomatic EPI $[67,68]$. Substitution of fatsoluble vitamins and other micronutrients (especially vitamin B12) might be necessary $[67,68]$. Individual dosing of pancreatic enzyme replacement with at least $40,000 \mathrm{U}$ of lipase per main meal and 10,000-25,000 U/snack is recommended for treatment of patients with EPI [69]. Notably, no specific dietary recommendations for patients with diabetes and EPI are available from interventional studies. In two previous studies, replacement therapy was associated with improved glycemic control or increased insulin and incretin response in patients with pancreatic disease and glucose intolerance [70, 71]. However, in a prospective study in patients with type 1 diabetes, enzyme replacement did not improve glycemic control [72].

\section{Conclusions}

EPI is highly prevalent in type 1 diabetes and common in type 2 diabetes, however, symptoms are usually mild and not necessarily reflected by increased fat excretion and reduced FE-1 levels underlining the necessity of improved diagnostic tests or algorithms. In patients with pancreatic disease, EPI often goes hand in hand in weight loss, malnutrition, osteoporosis, sarcopenia, and even increased mortality [73, 74]. The clinical consequences and optimal dietary treatment in patients with diabetes are less clear and need further investigations. The pathophysiology of EPI in type 1 and type 2 diabetes is not fully clear but includes inflammation, fibrosis, and steatosis of the exocrine pancreas and disturbances in the islet-acinar axis especially decreased trophic effects of insulin. In conclusion, although highly prevalent, EPI in both type 1 and type 2 diabetes remains a poorly understood disease of unclear clinical long-term significance.

Author Contributions B.R. and S. K both reviewed the literature and discussed relevant articles. B.R., G. R, and S.K. prepared the manuscript.

Funding Information Open access funding provided by University of Innsbruck and Medical University of Innsbruck.

\section{Compliance with Ethical Standards}

Competing Interests The authors declare that they have no competing interests.

Ethics Statement For the drafting of this manuscript, no studies on human or animal subject were conducted.

Open Access This article is licensed under a Creative Commons Attribution 4.0 International License, which permits use, sharing, adaptation, distribution and reproduction in any medium or format, as long as you give appropriate credit to the original author(s) and the source, provide a link to the Creative Commons licence, and indicate if changes were made. The images or other third party material in this article are included in the article's Creative Commons licence, unless indicated otherwise in a credit line to the material. If material is not included in the article's Creative Commons licence and your intended use is not permitted by statutory regulation or exceeds the permitted use, you will need to obtain permission directly from the copyright holder. To view a copy of this licence, visit http://creativecommons.org/licenses/by/4.0/.

\section{References}

Papers of particular interest, published recently, have been highlighted as:

- Of major importance

1. Lindkvist B. Diagnosis and treatment of pancreatic exocrine insufficiency. World J Gastroenterol. 2013;19(42):7258-66.

2. Pezzilli R, Andriulli A, Bassi C, Balzano G, Cantore M, Delle Fave $\mathrm{G}$, et al. Exocrine pancreatic insufficiency in adults: a shared position statement of the Italian Association for the Study of the Pancreas. World J Gastroenterol. 2013;19(44):7930-46.

3. Altay M. Which factors determine exocrine pancreatic dysfunction in diabetes mellitus? World J Gastroenterol. 2019;25(22):2699 705.

4. DiMagno EP, Go VL, Summerskill WH. Relations between pancreatic enzyme outputs and malabsorption in severe pancreatic insufficiency. N Engl J Med. 1973;288(16):813-5.

5. Singh VK, Haupt ME, Geller DE, Hall JA, Quintana Diez PM. Less common etiologies of exocrine pancreatic insufficiency. World J Gastroenterol. 2017;23(39):7059-76.

6. Zsori G, Illes D, Terzin V, Ivany E, Czako L. Exocrine pancreatic insufficiency in type 1 and type 2 diabetes mellitus: do we need to treat it? A systematic review. Pancreatology. 2018;S14243903(18)30111-X. https://doi.org/10.1016/j.pan.2018.05.006.

7. Dominguez-Munoz JE. Potential for screening for pancreatic exocrine insufficiency using the fecal elastase-1 test. Dig Dis Sci. 2017;62(5):1119-30.

8. Softeland E, Poulsen JL, Starup-Linde J, Christensen TT, Olesen SS, Singh S, et al. Pancreatic exocrine insufficiency in diabetes mellitus - prevalence and characteristics. Eur J Intern Med. 2019;68:18-22.

9. Cavalot F, Bonomo K, Fiora E, Bacillo E, Salacone P, Chirio M, et al. Does pancreatic elastase-1 in stools predict steatorrhea in type 1 diabetes? Diabetes Care. 2006;29(3):719-21.

10. Icks A, Haastert B, Giani G, Rathmann W. Low fecal elastase-1 in type I diabetes mellitus. Z Gastroenterol. 2001;39(10):823-30.

11. Vujasinovic M, Zaletel J, Tepes B, Popic B, Makuc J, Epsek Lenart $\mathrm{M}$, et al. Low prevalence of exocrine pancreatic insufficiency in patients with diabetes mellitus. Pancreatology. 2013;13(4):343-6.

12. Hardt PD, Hauenschild A, Nalop J, Marzeion AM, Jaeger C, Teichmann J, et al. High prevalence of exocrine pancreatic 
insufficiency in diabetes mellitus. A multicenter study screening fecal elastase 1 concentrations in 1,021 diabetic patients. Pancreatology. 2003;3(5):395-402.

13. Larger E, Philippe MF, Barbot-Trystram L, Radu A, Rotariu M, Nobecourt E, et al. Pancreatic exocrine function in patients with diabetes. Diabet Med. 2012;29(8):1047-54.

14. Mohapatra S, Majumder S, Smyrk TC, Zhang L, Matveyenko A, Kudva YC, et al. Diabetes mellitus is associated with an exocrine pancreatopathy: conclusions from a review of literature. Pancreas. 2016;45(8):1104-10.

15. Hardt PD, Hauenschild A, Jaeger C, Teichmann J, Bretzel RG, Kloer HU, et al. High prevalence of steatorrhea in 101 diabetic patients likely to suffer from exocrine pancreatic insufficiency according to low fecal elastase 1 concentrations: a prospective multicenter study. Dig Dis Sci. 2003;48(9):1688-92.

16. Hahn JU, Kerner W, Maisonneuve P, Lowenfels AB, Lankisch PG. Low fecal elastase 1 levels do not indicate exocrine pancreatic insufficiency in type-1 diabetes mellitus. Pancreas. 2008;36(3):2748.

17. Lindkvist B, Nilsson C, Kvarnstrom M, Oscarsson J. Importance of pancreatic exocrine dysfunction in patients with type 2 diabetes: a randomized crossover study. Pancreatology. 2018; pii: S14243903(18)30589-1. https://doi.org/10.1016/j.pan.2018.05.483.

18. Borbely Y, Plebani A, Kroll D, Ghisla S, Nett PC. Exocrine pancreatic insufficiency after Roux-en-Y gastric bypass. Surg Obes Relat Dis. 2016;12(4):790-4.

19.• Frost F, Kacprowski T, Ruhlemann M, Bulow R, Kuhn JP, Franke A, et al. Impaired exocrine pancreatic function associates with changes in intestinal microbiota composition and diversity. Gastroenterology. 2019;156(4):1010-5. 16S ribosomal RNA gene sequencing analysis of stool samples revealed a strong link between pancreatic elastase levels and microbiota diversity.

20. Sikkens EC, Cahen DL, Koch AD, Braat H, Poley JW, Kuipers EJ, et al. The prevalence of fat-soluble vitamin deficiencies and a decreased bone mass in patients with chronic pancreatitis. Pancreatology. 2013;13(3):238-42.

21. Shintakuya R, Uemura K, Murakami Y, Kondo N, Nakagawa N, Urabe K, et al. Sarcopenia is closely associated with pancreatic exocrine insufficiency in patients with pancreatic disease. Pancreatology. 2017;17(1):70-5.

22. Terzin V, Varkonyi T, Szabolcs A, Lengyel C, Takacs T, Zsori G, et al. Prevalence of exocrine pancreatic insufficiency in type 2 diabetes mellitus with poor glycemic control. Pancreatology. 2014;14(5):356-60.

23. el Newihi H, Dooley CP, Saad C, Staples J, Zeidler A, Valenzuela JE. Impaired exocrine pancreatic function in diabetics with diarrhea and peripheral neuropathy. Dig Dis Sci. 1988;33(6):705-10.

24. Hardt PD, Ewald N. Exocrine pancreatic insufficiency in diabetes mellitus: a complication of diabetic neuropathy or a different type of diabetes? Exp Diabetes Res. 2011;2011:761950.

25. Hellman B, Wallgren A, Petersson B. Cytological characteristics of the exocrine pancreatic cells with regard to their position in relation to the islets of Langerhans. A study in normal and obesehyperglycaemic mice. Acta Endocrinol (Copenh). 1962;39:465-73.

26. Hayden MR, Karuparthi PR, Habibi J, Lastra G, Patel K, Wasekar $\mathrm{C}$, et al. Ultrastructure of islet microcirculation, pericytes and the islet exocrine interface in the HIP rat model of diabetes. Exp Biol Med (Maywood). 2008;233(9):1109-23.

27. Lewis MP, Reber HA, Ashley SW. Pancreatic blood flow and its role in the pathophysiology of pancreatitis. J Surg Res. 1998;75(1): 81-9.

28. Murakami T, Fujita T. Microcirculation of the rat pancreas, with special reference to the insulo-acinar portal and insulo-venous drainage systems: a further scanning electron microscope study of corrosion casts. Arch Histol Cytol. 1992;55(5):453-76.
29. Murakami T, Fujita T, Miyake T, Ohtsuka A, Taguchi T, Kikuta A. The insulo-acinar portal and insulo-venous drainage systems in the pancreas of the mouse, dog, monkey and certain other animals: a scanning electron microscopic study of corrosion casts. Arch Histol Cytol. 1993;56(2):127-47.

30. Magkos F, Fabbrini E, Patterson BW, Eagon JC, Klein S. Portal vein and systemic adiponectin concentrations are closely linked with hepatic glucose and lipoprotein kinetics in extremely obese subjects. Metabolism. 2011;60(11):1641-8.

31. Mossner J, Logsdon CD, Goldfine ID, Williams JA. Regulation of pancreatic acinar cell insulin receptors by insulin. Am J Phys. 1984;247(2 Pt 1):G155-60.

32. Mossner J, Logsdon CD, Williams JA, Goldfine ID. Insulin, via its own receptor, regulates growth and amylase synthesis in pancreatic acinar AR42J cells. Diabetes. 1985;34(9):891-7.

33. Adler G, Kern HF. Regulation of exocrine pancreatic secretory process by insulin in vivo. Horm Metab Res. 1975;7(4):290-6.

34. Williams JA, Bailey AC, Preissler M, Goldfine ID. Insulin regulation of sugar transport in isolated pancreatic acini from diabetic mice. Diabetes. 1982;31(8 Pt 1):674-82.

35. Foulis AK, Stewart JA. The pancreas in recent-onset type 1 (insulin-dependent) diabetes mellitus: insulin content of islets, insulitis and associated changes in the exocrine acinar tissue. Diabetologia. 1984;26(6):456-61.

36. Butler AE, Galasso R, Matveyenko A, Rizza RA, Dry S, Butler PC. Pancreatic duct replication is increased with obesity and type 2 diabetes in humans. Diabetologia. 2010;53(1):21-6.

37.• Dirice E, De Jesus DF, Kahraman S, Basile G, Ng RW, El Ouaamari A, et al. Human duct cells contribute to beta cell compensation in insulin resistance. JCI Insight. 2019;4(8). https://doi.org/10.1172/ jci.insight. 99576 . The study for the first time shows that in settings of increased insulin demand such as insulin resistance ductal cells contribute to the compensatory beta cell pool by differentiation and/or neogenesis.

38. Barreto SG, Carati CJ, Toouli J, Saccone GT. The islet-acinar axis of the pancreas: more than just insulin. Am J Physiol Gastrointest Liver Physiol. 2010;299(1):G10-22.

39. Gittes GK. Developmental biology of the pancreas: a comprehensive review. Dev Biol. 2009;326(1):4-35.

40. Saisho Y, Butler AE, Meier JJ, Monchamp T, Allen-Auerbach M, Rizza RA, et al. Pancreas volumes in humans from birth to age one hundred taking into account sex, obesity, and presence of type-2 diabetes. Clin Anat. 2007;20(8):933-42.

41. Alexandre-Heymann L, Mallone R, Boitard C, Scharfmann R, Larger E. Structure and function of the exocrine pancreas in patients with type 1 diabetes. Rev Endocr Metab Disord. 2019;20(2):12949.

42. Alzaid A, Aideyan O, Nawaz S. The size of the pancreas in diabetes mellitus. Diabet Med. 1993;10(8):759-63.

43. Philippe MF, Benabadji S, Barbot-Trystram L, Vadrot D, Boitard C, Larger E. Pancreatic volume and endocrine and exocrine functions in patients with diabetes. Pancreas. 2011;40(3):359-63.

44. Hayden MR, Karuparthi PR, Habibi J, Wasekar C, Lastra G, Manrique $\mathrm{C}$, et al. Ultrastructural islet study of early fibrosis in the Ren2 rat model of hypertension. Emerging role of the islet pancreatic pericyte-stellate cell. JOP. 2007;8(6):725-38.

45. Hayden MR, Patel K, Habibi J, Gupta D, Tekwani SS, WhaleyConnell A, et al. Attenuation of endocrine-exocrine pancreatic communication in type 2 diabetes: pancreatic extracellular matrix ultrastructural abnormalities. J Cardiometab Syndr. 2008;3(4):234-43.

46. Haber PS, Keogh GW, Apte MV, Moran CS, Stewart NL, Crawford $\mathrm{DH}$, et al. Activation of pancreatic stellate cells in human and experimental pancreatic fibrosis. Am J Pathol. 1999;155(4):1087-95.

47. Apte MV, Haber PS, Darby SJ, Rodgers SC, McCaughan GW, Korsten MA, et al. Pancreatic stellate cells are activated by 
proinflammatory cytokines: implications for pancreatic fibrogenesis. Gut. 1999;44(4):534-41.

48. Nomiyama Y, Tashiro M, Yamaguchi T, Watanabe S, Taguchi M, Asaumi H, et al. High glucose activates rat pancreatic stellate cells through protein kinase $\mathrm{C}$ and $\mathrm{p} 38$ mitogen-activated protein kinase pathway. Pancreas. 2007;34(3):364-72.

49. Lee Y, Hirose H, Ohneda M, Johnson JH, McGarry JD, Unger RH. Beta-cell lipotoxicity in the pathogenesis of non-insulin-dependent diabetes mellitus of obese rats: impairment in adipocyte-beta-cell relationships. Proc Natl Acad Sci U S A. 1994;91(23):10878-82.

50. Begovatz P, Koliaki C, Weber K, Strassburger K, Nowotny B, Nowotny $\mathrm{P}$, et al. Pancreatic adipose tissue infiltration, parenchymal steatosis and beta cell function in humans. Diabetologia. 2015;58(7):1646-55.

51. Miyake H, Sakagami J, Yasuda H, Sogame Y, Kato R, Suwa K, et al. Association of fatty pancreas with pancreatic endocrine and exocrine function. PLoS One. 2018;13(12):e0209448.

52. Tahtaci M, Algin O, Karakan T, Yurekli OT, Alisik M, Koseoglu H, et al. Can pancreatic steatosis affect exocrine functions of pancreas? Turk J Gastroenterol. 2018;29(5):588-94.

53. Rodriguez-Calvo T, Ekwall O, Amirian N, Zapardiel-Gonzalo J, von Herrath MG. Increased immune cell infiltration of the exocrine pancreas: a possible contribution to the pathogenesis of type 1 diabetes. Diabetes. 2014;63(11):3880-90.

54. Kobayashi T, Nakanishi K, Kajio H, Morinaga S, Sugimoto T, Murase T, et al. Pancreatic cytokeratin: an antigen of pancreatic exocrine cell autoantibodies in type 1 (insulin-dependent) diabetes mellitus. Diabetologia. 1990;33(6):363-70.

55. Panicot L, Mas E, Thivolet C, Lombardo D. Circulating antibodies against an exocrine pancreatic enzyme in type 1 diabetes. Diabetes. 1999:48(12):2316-23.

56. Abu-El-Haija M, Conwell DL. Pancreatic insufficiency: what is the gold standard? Gastrointest Endosc Clin N Am. 2018;28(4):521-8.

57. Weaver LT, Amarri S, Swart GR. 13C mixed triglyceride breath test. Gut. 1998;43(Suppl 3):S13-9.

58. Vantrappen GR, Rutgeerts PJ, Ghoos YF, Hiele MI. Mixed triglyceride breath test: a noninvasive test of pancreatic lipase activity in the duodenum. Gastroenterology. 1989;96(4):1126-34.

59. Dominguez-Munoz JE. Diagnosis and treatment of pancreatic exocrine insufficiency. Curr Opin Gastroenterol. 2018;34(5):349-54.

60. Struyvenberg MR, Martin CR, Freedman SD. Practical guide to exocrine pancreatic insufficiency - breaking the myths. BMC Med. 2017;15(1):29.

61. Levy P, Barthet M, Mollard BR, Amouretti M, Marion-Audibert AM, Dyard F. Estimation of the prevalence and incidence of chronic pancreatitis and its complications. Gastroenterol Clin Biol. 2006;30(6-7):838-44.

62. Van de Vijver E, Desager K, Mulberg AE, Staelens S, Verkade HJ, Bodewes FA, et al. Treatment of infants and toddlers with cystic fibrosis-related pancreatic insufficiency and fat malabsorption with pancrelipase MT. J Pediatr Gastroenterol Nutr. 2011;53(1):61-4.

63. Lieb JG 2nd, Draganov PV. Pancreatic function testing: here to stay for the 21st century. World J Gastroenterol. 2008;14(20):3149-58.

64. Dominguez-Munoz JE, Hieronymus C, Sauerbruch T, Malfertheiner P. Fecal elastase test: evaluation of a new noninvasive pancreatic function test. Am J Gastroenterol. 1995;90(10): 1834-7.

65. Loser C, Mollgaard A, Folsch UR. Faecal elastase 1: a novel, highly sensitive, and specific tubeless pancreatic function test. Gut. 1996;39(4):580-6.

66. Siegmund E, Lohr JM, Schuff-Werner P. The diagnostic validity of non-invasive pancreatic function tests-a meta-analysis. Z Gastroenterol. 2004;42(10):1117-28.

67. Dominguez-Munoz JE, Phillips M. Nutritional therapy in chronic pancreatitis. Gastroenterol Clin N Am. 2018;47(1):95-106.

68. Dominguez-Munoz JE. Management of pancreatic exocrine insufficiency. Curr Opin Gastroenterol. 2019;35(5):455-9.

69. Hammer HF. Pancreatic exocrine insufficiency: diagnostic evaluation and replacement therapy with pancreatic enzymes. Dig Dis. 2010;28(2):339-43.

70. Ebert R, Creutzfeldt W. Reversal of impaired GIP and insulin secretion in patients with pancreatogenic steatorrhea following enzyme substitution. Diabetologia. 1980;19(3):198-204.

71. Knop FK, Vilsboll T, Larsen S, Hojberg PV, Volund A, Madsbad S, et al. Increased postprandial responses of GLP-1 and GIP in patients with chronic pancreatitis and steatorrhea following pancreatic enzyme substitution. Am J Physiol Endocrinol Metab. 2007;292(1): E324-30.

72. Ewald N, Bretzel RG, Fantus IG, Hollenhorst M, Kloer HU, Hardt $\mathrm{PD}$, et al. Pancreatin therapy in patients with insulin-treated diabetes mellitus and exocrine pancreatic insufficiency according to low fecal elastase 1 concentrations. Results of a prospective multicentre trial. Diabetes Metab Res Rev. 2007;23(5):386-91.

73. Perbtani Y, Forsmark CE. Update on the diagnosis and management of exocrine pancreatic insufficiency. F1000Res. 2019;26;8. https:// doi.org/10.12688/f1000research.20779.1.

74. de la Iglesia-Garcia D, Vallejo-Senra N, Iglesias-Garcia J, LopezLopez A, Nieto L, Dominguez-Munoz JE. Increased risk of mortality associated with pancreatic exocrine insufficiency in patients with chronic pancreatitis. J Clin Gastroenterol. 2018;52(8):e63-72.

75. Kaser S, Winhofer-Stöckl Y, Kazemi-Shirazi L, Hofer SE, Brath H, Sourij H, et al. Andere spezifische Diabetesformen und exokrine Pankreasinsuffizienz (Update 2019). 2019;131(Suppl 1):S16-26.

Publisher's Note Springer Nature remains neutral with regard to jurisdictional claims in published maps and institutional affiliations. 